\title{
Detection of Flexibacter psychrophilus by immunofluorescence in fish suffering from fry mortality syndrome: a rapid diagnostic method
}

\author{
E. Lorenzen ${ }^{1}$, N. Karas $^{2}$ \\ ' National Veterinary Laboratory (NVL), Hangøvej 2, DK-8200 Aarhus N, Denmark \\ ${ }^{2}$ Danish Trout Culture Research Station, Brøns Møllevej 7, DK-6780 Skærbæk, Denmark
}

ABSTRACT: A rapid diagnostic method for fry mortality syndrome is described. The method is based on immunofluorescence analysis of spleen imprints from diseased rainbow trout fry and utilizes rabbit antiserum prepared against Flexibacter psychrophilus. A low level of cross reactivity with Flexibacter columnaris was observed but this can be avoided by absorbing the diagnostic antiserum with $F$. columnaris.

During the last 6 to 7 yr there has been considerable mortality among fry and fingerlings of rainbow trout Oncorhynchus mykiss in Danish hatcheries due to fry mortality syndrome (FMS) (Lorenzen et al. 1991). The fish suffer from a severe anaemia and splenomegaly, and numerous bacterial cells can be found within the vascular system as well as in the haematopoietic tissue. The bacterium involved has been identified (authors' unpubl. data) as Flexibacter psychrophilus (formerly Cytophaga psychrophila; Bernardet \& Grimont 1989), the causative agent of cold water disease (Pacha \& Ordal 1970). Infection experiments have shown that the isolated bacterium can induce FMS. In accordance with this, infected fish can be cured by being given oxytetracycline in the feed (Lorenzen et al. 1991). Diseases very similar to FMS appear to cause the same problems in rainbow trout hatcheries in other European countries [Baudin-Laurencin et al. (1989) and Bernardet \& Kerouault (1989) (France); Hamlet Partnership pers. comm. (UK); Reyneri Marco pers. comm. (Italy)].

Using a phase contrast light microscope with a $\times 40$ objective lens, a presumptive diagnosis of FMS can be made through examination of wet mount preparations of the kidney, spleen or blood. The diagnosis is based on the presence of numerous, slender, non-motile rodshaped bacteria. However, it is not always possible to detect the bacteria, and the clinical signs are sometimes less distinct, making the diagnosis uncertain. Therefore kidney and spleen samples have usually been inoculated onto modified Anacker \& Ordal's agar (Anacker \& Ordal 1955) containing $0.7 \%$ agar (Difco) and either $5 \%$ newborn calf serum or $0.5 \%$ tryptone (Bernardet \& Grimont 1989), henceforth referred to as Anacker \& Ordals agar enriched (AOAE). Depending on the severity of the infection, 1 to $4 \mathrm{~d}$ may pass before colonies of Flexibacter psychrophilus develop. Diagnosis by culture therefore takes time. A further disadvantage of culture is that it may not succeed. In cases of material (kidney and spleen) submitted to the laboratory by mail, the survival of the bacterium can be considerably reduced (by $90 \%$ or more) if the temperature during shipment increases to more than $23^{\circ} \mathrm{C}$ for $17 \mathrm{~h}$ (authors' unpubl. data).

Due to the need for a rapid diagnostic method to detect viable as well as dead bacteria, we have developed a diagnostic immunofluorescence method that is based on an examination of spleen imprints from rainbow trout fry and fingerlings suffering from FMS.

Materials and methods. Spleen imprints: Spleen imprints measuring ca $5 \times 5 \mathrm{~mm}$ were made on microscope slides. Some of the spleens were removed from diseased or healthy fish that were brought to the laboratory alive or submitted on ice immediately after being killed. Others were submitted in transport tubes containing AOAE. The latter spleens were removed from diseased fish at the hatcheries as aseptically 
as possible (the surface of the fish was rubbed with alcohol prior to incision)

The study included fry or fingerlings from 25 outbreaks of FMS, 2 outbreaks of ERM (enteric redmouth disease) and 3 control sites. On average, 3 spleens from each outbreak were used, and 2 imprints per spleen per antiserum per antiserum dilution were made.

Preparations with cultured bacteria: As controls, droplets of broth-grown cells that had been washed twice in $0.1 \mathrm{M}$ phosphate buffered saline (PBS) were allowed to dry on microscope slides and then treated as described below for the imprints.

Immunofluorescence test: Immunofluorescence staining was performed as follows: imprints were fixed for $15 \mathrm{~min}$ in $3 \%$ paraformaldehyde in PBS and, after air-drying, were overlaid with $10 \mu \mathrm{l}$ of diluted rabbit antiserum (see below for further details) and incubated in a humid chamber for $30 \mathrm{~min}$ at $37^{\circ} \mathrm{C}$. Following a rinsing cycle $(2 \times 10 \mathrm{~min}$ in $0.85 \%$ aqueous $\mathrm{NaCl}$ containing $0.05 \%$ Tween-20 followed by $1 \times 10 \mathrm{~min}$ in de-ionized water also containing $0.05 \%$ Tween-20), $10 \mu \mathrm{l}$ of tetramethyl rhodamine isothiocyanate (TRITC) conjugated swine anti-rabbit Ig (DAKO-PATTS, Denmark) diluted 1:100 in PBS were added and the imprints were incubated for $30 \mathrm{~min}$ at $37^{\circ} \mathrm{C}$ in a humid chamber. After another rinsing cycle, cover glasses were mounted on the imprints in PBS-buffered glycerol and the imprints were examined with an Olympus Vanox epifluorescence microscope equipped with a $200 \mathrm{w}$ mercury lamp, a filter unit for TRITC, and $\times 40$ and $\times 100$ fluorescence oil objectives. Altogether, the staining procedure was completed in 3.5 to $4 \mathrm{~h}$.

Rabbit antisera: Antisera to one of the Danish isolates of Flexibacter psychrophilus (Strain 911209-1) as well to $F$. columnaris (NCMB $2248^{\mathrm{T}}$ ) were prepared as described by Lancefield et al. (1975) with a few modifications: New Zealand white rabbits were given 9 intravenous injections of the bacterial suspension $(1 \times$ $10^{8}$ formalin-killed cells $\mathrm{ml}^{-1}$ ) in PBS over a period of $3 \mathrm{wk}$. The first 3 injections were $0.5 \mathrm{ml}$ and the subsequent 6 injections were $1.0 \mathrm{ml}$. The rabbits were bled $8 \mathrm{~d}$ after the last injection. The titer of agglutinating antibodies of the antisera to F. psychrophilus (9112091) and to $F$. columnaris (NCMB $2248^{\mathrm{T}}$ ) were found to be $1: 128$ and $1: 64$, respectively. Antiserum to the type strain of F. psychrophilus (NCMB $1947^{\mathrm{T}}$ ) was prepared as described by Lehmann et al. (1991) and its titer was 1:256. Antiserum to Yersinia ruckeri (Danish strain, Strain 45/85) was prepared as described by Olesen (1991) and it had a titer of 1:32768.

The antisera were diluted 1:100, 1:300 and 1:900 in PBS. The antiserum to the type strain of Flexibacter psychrophilus (NCMB $1947^{\mathrm{T}}$ ) was used only on spleen imprints from 4 out of 25 outbreaks of FMS, our purpose being to test the serological relatedness of the
Danish strains to the type strain at the immunofluorescence level. The antisera to $F$. columnaris and to $Y$. ruckeri were used in ca 10 of the 25 outbreaks of FMS to test for possible cross reactivity. F. columnaris has not yet been detected in Denmark, whereas Y. ruckeri, the causative agent of ERM, is widespread there.

Results and discussion. The spleen imprints from fry and fingerlings suspected of suffering from FMS reacted with dilutions of the antiserum to Flexibacter psychrophilus (911209-1) up to at least 1:900 (Table 1). Likewise, in the 4 cases tested, the antiserum to the type strain F. psychrophilus (NCMB 1947 ${ }^{\mathrm{T}}$ ) also detected the bacterium at serum dilutions of at least 1:900, indicating a close relationship at the immunofluorescence level between the Danish strains and the type strain of $F$. psychrophilus. The antiserum to F. columnaris (NCMB 2248 ) diluted 1:100 showed a low level of cross reactivity with the bacterium in the imprints. However, this could be minimized by cross absorption with $F$. psychrophilus (911209-1). The cross absorption was performed overnight using $1 \mathrm{ml}$ anti-

Table 1. Summary of immunofluorescence results on spleen imprints and cultured bacterial cells treated with different rabbit antisera ${ }^{\alpha}$ FMS: Fry mortality syndrome; ERM: enteric redmouth disease; nd: not done

\begin{tabular}{|c|c|c|c|}
\hline \multirow[t]{2}{*}{ Antisera } & \multicolumn{2}{|c|}{$\begin{array}{l}\text { Imprints of spleens } \\
\text { from fish with: }\end{array}$} & \multirow{2}{*}{$\begin{array}{l}\text { Broth-cultured } \\
\text { cells of Flexi- } \\
\text { bacter columnaris } \\
\text { (NCMB } 2248^{\mathrm{T}} \text { ) }\end{array}$} \\
\hline & $\mathrm{FMS}^{\mathrm{b}}$ & ERM $^{\mathrm{C}}$ & \\
\hline \multicolumn{4}{|c|}{ Anti Flexibacter psychrophilus (911209-1) } \\
\hline $1: 100$ & + & - & + \\
\hline 1.300 & + & - & - \\
\hline 1.900 & + & - & - \\
\hline \multicolumn{4}{|c|}{ Anti Flexibacter psychrophilus (NCMB $1947^{\top}$ ) } \\
\hline 1100 & + & nd & nd \\
\hline 1. 300 & + & nd & nd \\
\hline 1. 900 & + & nd & nd \\
\hline \multicolumn{4}{|c|}{ Anti Flexibacter columnaris (NCMB $2248^{\mathrm{T}}$ ) } \\
\hline $1 \cdot 100$ & + & - & + \\
\hline $1: 300$ & - & - & + \\
\hline $1: 900$ & - & - & + \\
\hline \multicolumn{4}{|c|}{ Anti Yersina ruckeri $(45 / 85)$} \\
\hline 1100 & - & + & - \\
\hline 1.300 & - & + & - \\
\hline 1.900 & - & + & - \\
\hline \multicolumn{4}{|c|}{$\begin{array}{l}\text { In addition (not shown) the study included } 10 \text { spleen } \\
\text { imprints from fry originating from farms without FMS or } \\
\text { from the National Veterinary Laboratory. These imprints } \\
\text { proved negative with all antisera and all dilutions of the } \\
\text { antisera tested } \\
\text { b Study included spleen imprints from } 25 \text { outbreaks of } \\
\text { FMS } \\
\text { "Study included spleen imprints from } 2 \text { confirmed out- } \\
\text { breaks of ERM }\end{array}$} \\
\hline
\end{tabular}


serum:1 ml bacterial suspension containing $1 \times 10^{8}$ heat-killed cells in PBS. Similarly, cross reactivity of antiserum to $F$. psychrophilus (911209-1) at dilution 1:100 with $F$ columnaris (NCMB $2248^{\mathrm{T}}$ ) cells could be removed by cross absorption with the latter bacterium.

In contrast, the antiserum to Yersinia ruckeri did not cross react with spleen imprints containing Flexibacter psychrophilus or F. columnaris cells. Further, the antiserum to $Y$. ruckeri was the only antiserum in this study that reacted with spleen imprints from fish suffering from ERM.

If imprints from fish suspected of suffering from FMS were made from spleens of fish brought to laboratory alive, the bacterium was usually very well preserved and its rod-shaped morphology was evident (Fig. 1a). The bacterial cells fluoresced brilliantly whereas the spleen cells were hardly visible. Likewise, the spleen cells from healthy control fry were not stained with any of the antisera used (Fig. 1b)

If, on the other hand, the spleens were taken from fish which had been dead for some time, or if they had
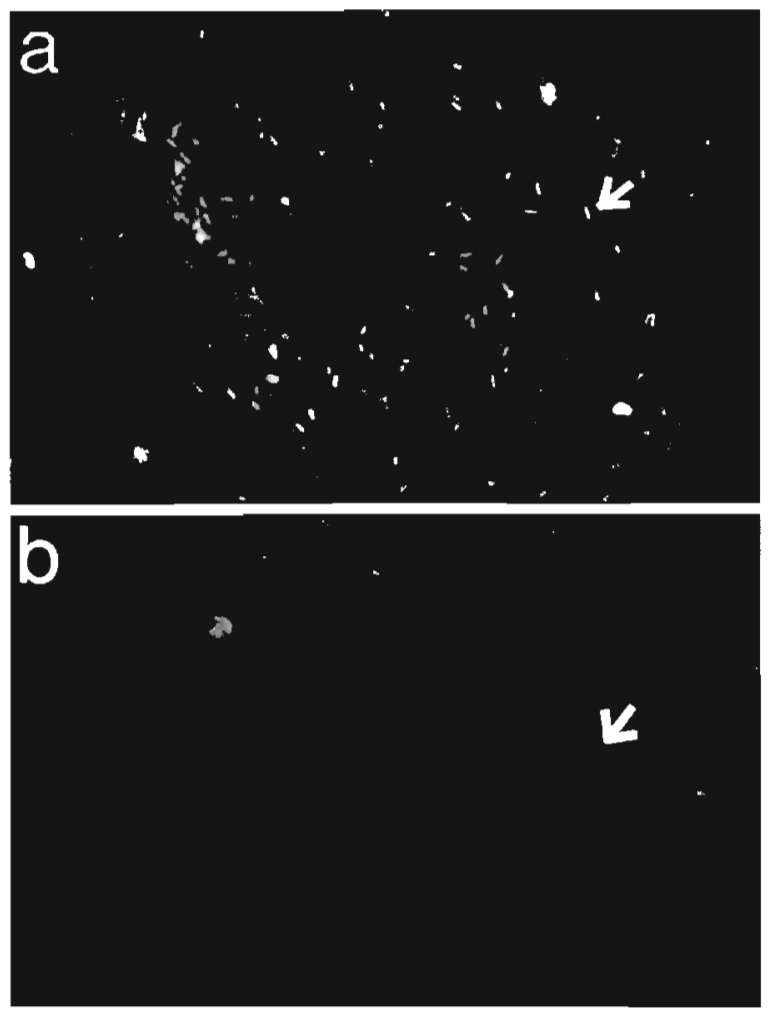

Fig. 1. Onchorhyncus mykiss, Flexibacter psychrophilus. (a) Spleen imprint from a fry suffering from FMS. Treated with anti $F$. psychrophilus (911209-1) antiserum diluted 1:100. Bacteria are brilliantly stained (arrow), whereas spleen cells are barely visible. $(\times 840)$. (b) Spleen imprint from a healthy fry Treated with anti F. psychrophilus (911209-1) antiserum diluted 1:100. Spleen cells are hardly visible (arrow). $(\times 840)$ been submitted to the laboratory in transport tubes with AOAE, the bacteria were often less well-preserved, and their morphology was not easily distinguishable. In this case, the staining intensity was the deciding factor: such imprints treated with the antisera to Flexibacter psychrophilus were brilliantly stained with antiserum dilutions up to at least 1:900; in contrast, such imprints treated with antiserum to F. columnaris were only stained at dilution 1:100 and imprints treated with antiserum to Yersinia ruckeri were not stained at all.

The present study included spleen imprints from 25 clinical outbreaks of FMS at Danish hatcheries during 1991-92. In all of the 25 suspected FMS cases, the spleen imprints were positive by immunofluorescence, i.e. they gave positive reaction with the antiserum to Flexibacter psychrophilus (911209-1) diluted up to at least 1:900. Furthermore, according to the fish farmers involved, the fish were cured by administration of oxytetracycline in the feed. Only in 17 cases were yellow-pigmented bacteria, identified morphologically, biochemically and serologically as F. psychrophilus, successfully cultured from the spleens on AOAE. In 8 cases no colonies developed after inoculation. The spleens in those cases had been submitted to the laboratory in transport tubes, and although the samples were refrigerated at dispatch, the temperature at arrival was sometimes around room temperature and may have exceeded $23^{\circ} \mathrm{C}$ during shipment. Such temperatures have been shown to reduce the survival of the bacterium by $90 \%$ or more within $17 \mathrm{~h}$ (authors unpubl. data). This temperature susceptibility is in accordance with the formal description of the bacterium provided by Bernardet \& Grimont (1989). According to these authors, very few strains are able to grow at $25^{\circ} \mathrm{C}$.

In conclusion, in relation to FMS, the immunofluorescence technique appears to be a very quick and reliable diagnostic method, and it detects viable as well as dead bacteria in spleen imprints. The latter property is especially important as the bacterium involved appears to be relatively heat-sensitive.

Acknowledgements. The authors thank Niels Lorenzen, Niels Jørgen Olesen and P. E. Vestergaard Jorgensen at the National Veterinary Laboratory in Aarhus for suggesting trials with the immunofluorescence technique as well as for valuable discussions concerning interpretation of the results. Niels Jørgen Olesen is also acknowledged for providing the rabbit antiserum to Yersinia ruckeri (strain 45/85). We also thank Jean-Francois Bernardet at INRA, Jouy-en-Josas, France, for kindly providing the rabbit antiserum to the type strain of Flexibacter psychrophilus. The Danish Trout Industry and the Danish Trout Feed Producers are acknowledged for supporting the study. 


\section{LITERATURE CITED}

Anacker, R. L., Ordal, E. J. (1955). Study of a bacteriophage infecting the myxobacterium Chondrococcus columnaris J. Bact 70: 738-741

Baudin-Laurencin, F., Castric, J.-C., Vigneulle, M., Tixerant, G. (1989). La Myxobactériose viscérale de la truite arc-enciel Salmo gairdneri $R$ : une forme nouvelle de la maladie de l'eau froide á Cytophaga psychrophila. Bull. Acad. Vet. Fr. 62: 147-157

Bernardet, J.-F., Grimont, P. A. D. (1989). Deoxyribonucleic acid relatedness and phenotypic characterization of Flexibacter columnaris sp. nov., nom. rev., Flexibacter psychrophilus sp. nov., nom. rev., and Flexibacter maritimus Wakabayashi, Hikida, and Masumura 1986. Int. J. Syst. Bact. 39: 346-354

Bernardet, J.-F., Kerouault, B. (1989). Phenotypic and genomic studies of 'Cytophaga psychrophila' isolated from diseased rainbow trout (Oncorhynchus mykiss) in France. Appl. environ. Microbiol. 55: 1796-1800

Responsible Subject Editor: T. Evelyn, Nanaimo, B.C., Canada
Lancefield، R. C., McCarty, M., Everly, W. N. (1975). Multiple mouse-protective antibodies directed against Group B streptococci. J. exp. Med. 142: 165-179

Lehmann, J., Mock, D., Stürenberg. F.-J., Bernardet, J.-F. (1991) First isolation of Cytophaga psychrophila from a systemic disease in eel and cyprinids. Dis. aquat. Org. 10: $217-220$

Lorenzen, E., Dalsgaard, I., From, J., Hansen, E. M., Hørlyck, V., Korsholm, H., Mellergaard, S., Olesen, N. J. (1991). Preliminary investigations of fry mortality syndrome in rainbow trout Bull. Eur. Ass. Fish Path. 11: 77-79

Olesen, N. J. (1991). Detection of the antibody response in rainbow trout following immersion vaccination with Yersinia ruckeri bacterins by ELISA and passive immunization. J. appl. Ichthyol. 7: 36-43

Pacha, R. E., Ordal, E. J. (1970). Myxobacterial diseases of salmonids. Am. Fish. Soc. Special Publ. No. 5: 243-257

Manuscript first received: January 22, 1992

Revised version acccpted: June 19, 1992 